\title{
Effects of weather variability on sheep and beef farming in northern Southland, New Zealand: A modelling analysis
}

\author{
F.Y. LI ${ }^{1}$, R. VIBART ${ }^{1}$, R.A. DYNES ${ }^{2}$, I. VOGELER ${ }^{1}$ and M. BROWN ${ }^{1}$ \\ ${ }^{1}$ AgResearch Grasslands, Private Bag 11008, Palmerston North 4442 \\ ${ }^{2}$ AgResearch Lincoln, Private Bag 4749, Christchurch 8140
}

\begin{abstract}
Inter-annual weather variation has profound effects on pasture production and pastoral farm performance. However, the relationship between the variation in herbage and animal production and farm economic and environmental (nitrate leaching and greenhouse gas emission) outcomes are not clearly quantified, especially with varying farm management strategies applied under variable weather scenarios. We used a pasture model (APSIM-AgPasture), corroborated by measured pasture growth data, to generate pasture growth curves for a typical sheep and beef farm in northern Southland for the past 39 years, and grouped them into five weather scenarios. We fed these curves into a farm system model (Farmax) to examine the changes in farm performance with various management adaptations. We found that farm economic and environmental outcomes did not respond proportionally to pasture production; compared with the variation range in herbage production, the variation range in animal production was smaller, but the variation range in farm profitability was larger. Environmental efficiency (nitrate leaching and greenhouse gas emissions per unit of animal products) was high in wet years. Our results highlight the importance of considering the nonproportional changes among pasture production, animal production, profitability, and environmental outcomes of pastoral farming when selecting farm management strategies and tactics to adapt to weather variations, and indicate the necessity of incorporating these non-linear relationships in the development of farm management decision support tools.
\end{abstract}

Key words: Climate variability, pasture herbage production, animal production, production efficiency, environmental efficiency, management adaptation

\section{Introduction}

Large inter-annual variation in weather conditions, especially in rainfall during the pasture growing season, has profound impacts on pasture production in many parts of New Zealand (Radcliffe 1974; Li et al. 2011). Variation in pasture production subsequently affects the productivity, financial and environmental outcomes of livestock farms, requiring adaptive management (Smit et al. 1996). The effects of weather variation, especially drought events, on pasture production and livestock production have been widely reported (e.g., Burton \& Peoples 2008; MAF 2008); the strategies and tactics used by farmers to cope with climatic variation have also been investigated (e.g., Gray et al. 2008). However, the relationships between the variation in pasture herbage and animal production, as well as farm financial and environmental outcomes (nitrate leaching and green house gas emissions), have not been clearly quantified, especially incorporating farm management strategies designed to cope with weather variation.

Large variation in pasture production across years can be buffered through management adaptations, thus the variation in animal production can be smaller than that of pasture production. However, the smaller variation in animal production achieved through management adaptations may not necessarily lead to a smaller variation in farm profitability and environmental outcomes because of the changes in farm biological conditions and management-associated expenditures. The objective of this paper is to understand and quantify the relationship between variation in pasture herbage production, animal production, and farm financial and environmental indicators in response to inter-annual weather fluctuation under simple proactive management adaptations, through pasture and pastoral farm system modelling. These relationships vary with farm system settings and choices of management strategies and tactics. This case study simulates a typical sheep and beef farm in northern southland. These relationships are helpful to farmers when selecting adaptive management strategies; and are fundamental to understand farmers' decision-making for developing framework and tools to explore the farm systems behaviour under the influence of multiple drivers of market, policy and climate change (Wedderburn et al. 2011).

\section{Methods}

\section{Base model farm}

A typical sheep and beef farm in northern Southland (herein Base farm, Class 6, Beef and Lamb New Zealand 2010; MAF 2010) was modelled. The farm comprises an extensive type of finishing operation, and is the dominant sheep and beef farm class in the South Island (Manhire 2010). The farm has an effective 
area of 450 ha, $70 \%$ of which is flat-to-rolling ( $315 \mathrm{ha}$ ) and $30 \%$ is hill land (135 ha). The Base farm carried 2620 Romney ewes, 62 crossbred cows and 52 hinds during the winter, a total of $c a$. 5700 stock units (SU: $1 \mathrm{SU}=550 \mathrm{~kg} \mathrm{DM} /$ year), with a sheep/cattle/deer ratio of 72:25:3. Stock units also included contract, onfarm grazing of 125 Friesian heifers. On-farm grown supplements of winter feed (swedes, 28 ha) and hay were used. Nitrogen fertiliser was applied in early spring to 150 ha in the flat-to-rolling paddocks at a rate of $28 \mathrm{~kg} \mathrm{~N} / \mathrm{ha}$ (single application).

\section{Models used}

The AgPasture model (Li et al. 2011) in Agricultural Production System Simulator (APSIM version 7.3; Keating et al. 2003) was used to generate pasture growth curves over a 39-year period (1971-2009). It was assumed that yields from forage swedes varied in the same proportion as did pasture production under various weather scenarios tested. Farmax ${ }^{\circledR}$ Pro (version 6.4.5.23) was used to examine feed flow, nutrients offered and required, and key physical and financial data of the farm systems. The Overseer ${ }^{\circledR}$ model (version 5.4.9; Wheeler et al. 2008) was used to examine farm environmental outcomes.

\section{Modelling scenarios}

Pasture production curves were simulated assuming a ryegrass/clover pasture in a location close to Lumsden (45.74S, 168.44E). Meteorological data was obtained from the Virtual Climate Station (VCS; Tait et al. 2006) for the site. Annual mean precipitation was $871 \mathrm{~mm}$, and annual mean temperature was $10.1^{\circ} \mathrm{C}$. The northern Southland soil types Waikoikoi and Wendon were chosen as representative of the flat-to-rolling and hill portions of the farm respectively to parameterise the APSIM soil module based on their descriptions in New Zealand Soil Database (Wilde 2003) and on regional Soil Information Sheets (Environment Southland 2012). Wendon soils cover undulating to steep slopes of hilly land in northern and eastern Southland. They are well drained silt loam soils, with a shallow rooting depth $(45 \mathrm{~cm})$. Waikoikoi soils have a slightly deeper potential rooting depth, and a silt loam texture, but are poorly drained due to a fragipan at $50-60 \mathrm{~cm}$ depth.

Pasture growth curves over the 39-year period (1971-2009) were simulated for flat-to-rolling and hill land, and used to produce an average pasture growth curve for the farm. Five weather scenarios were categorised based on total annual pasture production. Annual pasture growth curves typical of these weather scenarios were calculated as the mean pasture growth rates in the years that fall into each of these under weather scenarios. These scenarios were the Bottom (mean of the three least producing years), $Q 1$ (mean of the lower half), Base (overall mean), Q3 (mean of top half) and Top (mean of the three best producing years).

\section{Farm management adaptations}

The five annual pasture growth curves were used to parameterise Farmax. The same farm conditions were set at the beginning of the year (nominal, from 1 July 2010 to 30 June 2011), including initial pasture cover $(1150 \mathrm{~kg} \mathrm{DM} / \mathrm{ha})$, stock numbers and stored feed. Simple management rules were used to respond to changes in pasture production in a proactive fashion, primarily to maintain a healthy and high quality sward. Only tactical adaptations (i.e., short-term managerial adjustment (Smit et al. 1996); short-term responses to immediate climatic conditions (Burton \& Peoples 2008)) were used to adapt the farm to shortages or excess pasture growth to keep it biologically feasible (i.e. matching feed supply with feed demand) and financially sound. Farmax was run in a long-term mode with the same pasture cover and breeding stock numbers at the beginning and end of each year. The adaptations included varying temporal winter forage crop utilisation, buying supplemental feed when needed (hay bales, regardless of the amount of home-made hay that was sold immediately after making), altering the number of contract grazing dairy heifers, and to a lesser extent, the adjustment of stock live weight gains. Weather variation affects animal reproduction efficiencies, and the magnitude of the effects depends on management. Reproduction efficiencies were kept the same among all scenarios tested in this modelling (ewe lambing/weaning and cow calving/weaning percentages were $130 / 126 \%$ and $85 / 84 \%$ respectively, values similar to those in Vibart et al. (2011)), while animal production (meat and wool, less importantly velvet, $\mathrm{kg}$ ) were affected by weather scenarios. In addition, farm biophysical characteristics were exported from Farmax to Overseer, to estimate nutrient losses (i.e., $\mathrm{N}$ leaching) and greenhouse gas (GHG) emissions.

\section{Results and Discussion}

\section{Weather variability and pasture production}

Annual pasture production differed markedly between the flat-to-rolling land (Base $=9.8$, Bottom $=7.2, \mathrm{Top}$ $=12.3 \mathrm{t} \mathrm{DM} / \mathrm{ha}$ ) and hill land (Base $=5.7$, Bottom $=$ 3.3, Top $=7.4 \mathrm{t} \mathrm{DM} /$ ha) (Fig. 1). The area-weighted average pasture growth curves on the farm showed a large variation in response to weather (Base $=8.5$, Bottom $=6.0, T o p=10.0 \mathrm{t} \mathrm{DM} / \mathrm{ha}$ ), especially during summer (December to March; Fig 1c), indicating the predominant effects of summer drought on pasture production in the region (Radcliffe 1974). 


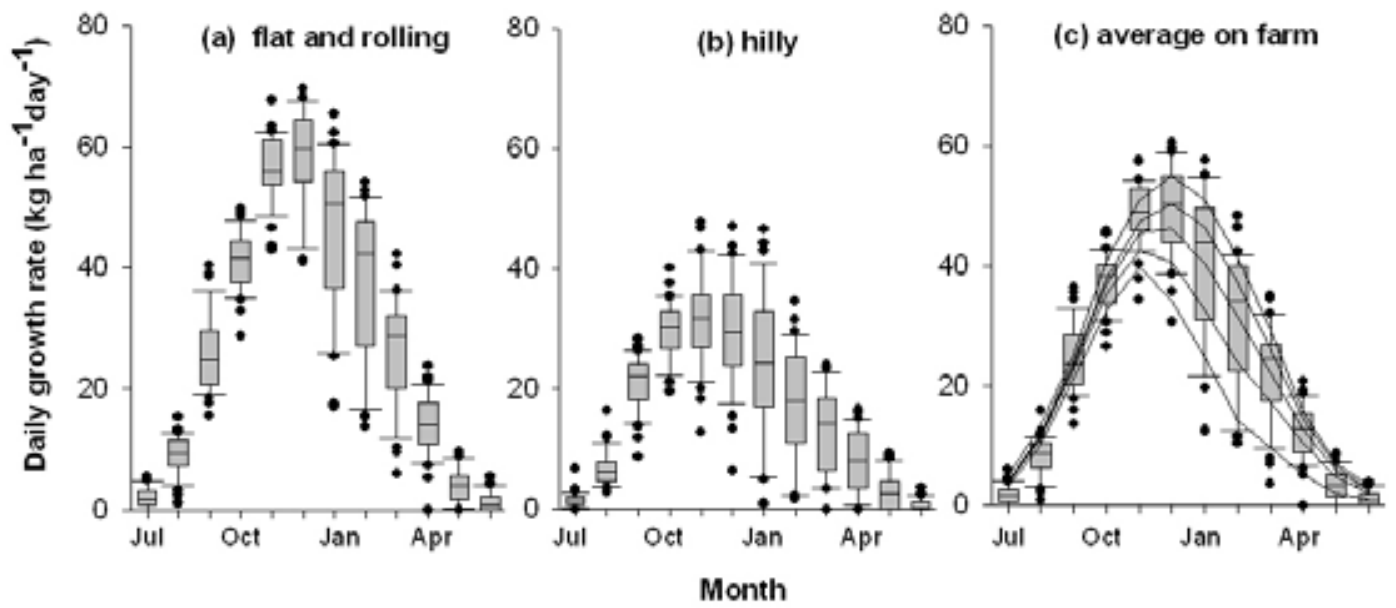

Figure 1. Variation of monthly pasture growth rates over the simulated period 1971-2010 on two land classes (a) flat to rolling land (Waikoikoi soil) and (b) hills (Wendon soil), and their weighted average at farm scale (c). The five lines on (c) represent pasture growth rates in a year of bottom $8 \%$ (= mean of three bottom years), lower quarter (Q1 = mean of the bottom half), base (overall mean), upper quarter (Q3 = mean of the upper half), and top $8 \%$ (= mean of three top years) of annual pasture production.

Farm management adaptation to five scenarios

Various farm management adaptations were applied to make the farm biologically feasible and financially sound under different pasture production scenarios (Table 1). Similar pasture cover curves (standing biomass) were obtained through management adaptation under four of the five scenarios, except for the Bottom scenario. Pasture covers were about 1200 , 2400 and $2250 \mathrm{~kg} \mathrm{DM} / \mathrm{ha}$ in September, December and March, respectively, for the Top, Q3, Base and Q1 scenarios; the pasture cover for the Bottom scenario was markedly lower during the summer/autumn period. The Base farm produced $294 \mathrm{t}$ DM of a winter forage crop (swedes; $10.5 \mathrm{t} \mathrm{DM} / \mathrm{ha}$ ) and produced 480 extra big bales of hay $(230 \mathrm{~kg} \mathrm{DM} / \mathrm{bale})$. Animals started grazed winter crop in May and $24 \%$ of it was used by the end of June (Table 1). Under the Bottom scenario, with less pasture production $(6.0 \mathrm{tDM} / \mathrm{ha})$ and stocking

Table 1. Pasture production and tactical strategies adopted by a sheep and beef farming system under five pasture production scenarios induced by inter-annual weather variation.

\begin{tabular}{|c|c|c|c|c|c|}
\hline \multirow[b]{2}{*}{ Item } & \multicolumn{5}{|c|}{ Pasture production scenarios ${ }^{1}$} \\
\hline & Bottom & Q1 & Base & Q3 & Top \\
\hline \multicolumn{6}{|l|}{ Annual forage production } \\
\hline Pasture (t DM/ha) & 6.0 & 7.4 & 8.4 & 9.2 & 10.0 \\
\hline Forage crop (FC; t DM) & 210 & 258 & 294 & 319 & 322 \\
\hline$\%$ FC grazed by 30 June & 62 & 27 & 24 & 28 & 26 \\
\hline \multicolumn{6}{|l|}{ Supplemental feed } \\
\hline Hay produced/imported (bales) ${ }^{2}$ & $0 / 2246$ & $200 / 362$ & $480 / 269$ & $720 / 312$ & $960 / 267$ \\
\hline \multicolumn{6}{|l|}{ Contract grazing (animal numbers) } \\
\hline Dairy heifers ${ }^{3}$ & - & 32 & 125 & 197 & 260 \\
\hline \multicolumn{6}{|l|}{ Species percentage ${ }^{4}$} \\
\hline Sheep & 82 & 78 & 72 & 67 & 63 \\
\hline Beef & 15 & 18 & 25 & 30 & 34 \\
\hline Deer & 3 & 3 & 3 & 3 & 3 \\
\hline Stocking rate (SU/ha) & 10.9 & 11.4 & 12.7 & 13.3 & 14.2 \\
\hline
\end{tabular}

1 The five scenarios are Bottom: mean of the three least producing years, Q1: mean of the lower half, Base: overall mean, Q3: mean of top half, and Top: mean of the three best producing years;

2 The hay produced - imported is the net surplus after meeting the animal feed demand on annual basis $(1 \mathrm{bale}=230 \mathrm{~kg} D M)$;

${ }^{3}$ In on 1 May (170 kg LW), out 12 months later at $459 \mathrm{~kg} \mathrm{LW}$ (Base scenario).

${ }^{4}$ Based on dry matter intake. 
(a) Production and Economics

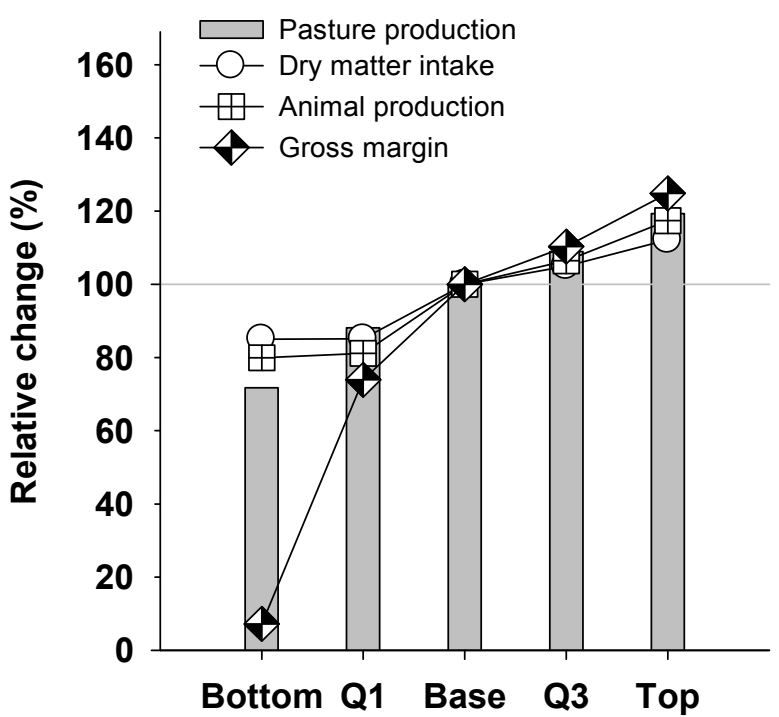

Weather scenarios

\section{(b) Environmental impacts}

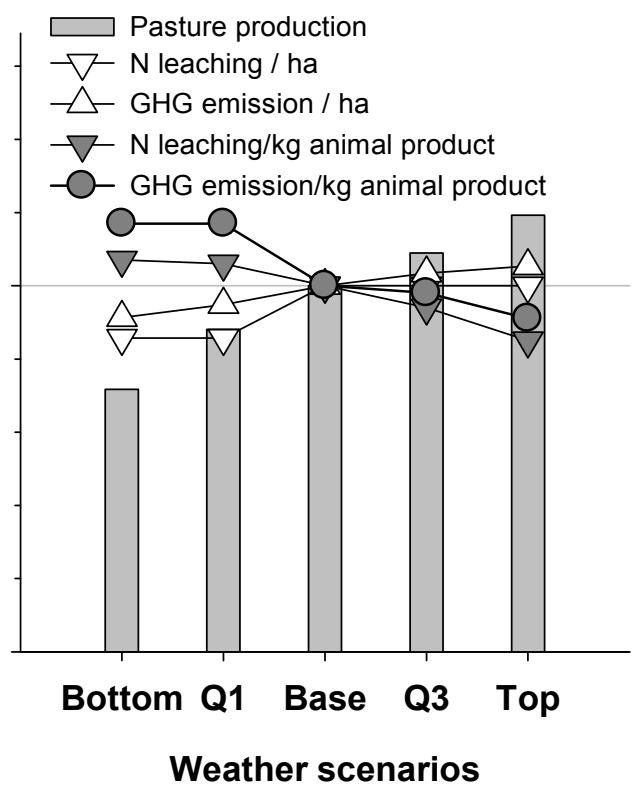

Figure 2. Weather induced variation in pasture production, farm economics and environmental outcomes. Relative changes against an average weather year in (a) pasture and animal production and farm economics; and (b) farm greenhouse gas emission and nitrate leaching. The horizontal grey line is a reference line (no relative change). The five scenarios are the same as in Figure 1.

Table 2. Major farm performance indicators in animal production, farm economics and environmental impacts under the five pasture production scenarios induced by inter-annual weather variation.

\begin{tabular}{|c|c|c|c|c|c|}
\hline \multirow[b]{2}{*}{ Item } & \multicolumn{5}{|c|}{ Pasture production scenarios ${ }^{1}$} \\
\hline & Bottom & Q1 & Base & Q3 & Top \\
\hline \multicolumn{6}{|l|}{ Animal production } \\
\hline Animal products $(\mathrm{AP}, \mathrm{kg} / \mathrm{ha})^{2}$ & 211 & 214 & 264 & 280 & 310 \\
\hline Meat & 167 & 170 & 220 & 237 & 266 \\
\hline Wool & 44 & 44 & 44 & 43 & 44 \\
\hline Velvet & 0.01 & 0.01 & 0.01 & 0.01 & 0.01 \\
\hline Dry matter intake (DMI, kg/ha) & 6220 & 6560 & 7340 & 7690 & 8230 \\
\hline Feed conversion efficiency & 28.5 & 28.2 & 26.5 & 26.1 & 25.2 \\
\hline \multicolumn{6}{|c|}{ Greenhouse gas (GHG) emissions and nitrogen $(N)$ losses } \\
\hline GHG emissions $\left(\mathrm{kg} \mathrm{CO}_{2}-\mathrm{e} / \mathrm{ha}\right)^{3}$ & 4280 & 4447 & 4689 & 4847 & 4942 \\
\hline GHG emissions $\left(\mathrm{kg} \mathrm{CO}_{2}-\mathrm{e} / \mathrm{kg} \mathrm{AP}\right)^{4}$ & 20.3 & 20.3 & 17.4 & 17.0 & 15.8 \\
\hline Nitrate leaching (kg N/ha) & 6.0 & 6.0 & 7.0 & 7.0 & 7.0 \\
\hline Nitrate leaching (kg N/kg AP) & 0.028 & 0.028 & 0.027 & 0.025 & 0.023 \\
\hline \multicolumn{6}{|l|}{ Financial information } \\
\hline Total revenue $(\$)^{5}$ & 329,932 & 366,566 & 445,087 & 484,798 & 531,517 \\
\hline Total expenditure $(\$)^{6}$ & 307,751 & 143,901 & 143,973 & 153,194 & 156,024 \\
\hline Gross margin $(\$ / \mathrm{ha})$ & 48 & 495 & 669 & 737 & 834 \\
\hline \multicolumn{6}{|c|}{$\begin{array}{l}1 \text { The five scenarios are Bottom: mean of the three least producing years, Q1: mean of the lower half, Base: overall mean, Q3: } \\
\text { mean of top half, and Top: mean of the three best producing years; } \\
2 \text { includes meat, fibre and velvet; } \\
{ }^{3} \mathrm{GHG} \text { include methane, nitrous oxide and carbon dioxide; } \\
{ }^{4} \mathrm{~kg} \mathrm{CO} \mathrm{C}_{2} \text { e per kg animal product (kg carcass, net growth + } \mathrm{kg} \text { wool or net growth); } \\
{ }^{5} \text { includes stock sales minus purchases, revenue from contract grazing, and sale of hay made on-farm; } \\
6 \text { includes costs related to forage crops and feed (i.e. hay making, imported feed, } \mathrm{N} \text { applied) and stock costs (i.e. animal health } \\
\text { and shearing). }\end{array}$} \\
\hline
\end{tabular}


rate (10.9 SU/ha), the farm imported 2246 hay bales for winter feeding. Also, animals were forced to graze the winter forage crop early, starting in March, and $62 \%$ of the winter crop was used by the end of June. In contrast, under the Top scenario, with more pasture $(10.0 \mathrm{t} \mathrm{DM} /$ ha) and winter forage crop (12.5 t DM/ha) produced, a higher stocking rate (14.2 SU/ha) was achieved, from more contract on-farm grazing of dairy heifers, and more bales of hay sold (see details in Table 1). Changes in animal numbers are also a tactical response to varying pasture production (Burton \& Peoples 2008; Gray et al. 2008). For the purpose of financial comparison in this modelling exercise, the same pasture cover and breeding animal numbers were achieved at the end as at the beginning of each year, allowing comparison of farm financial performance under different scenarios and avoiding explicit calculation of the follow-on effects of different weather and management across years.

\section{Variations of farm productivity, profitability and environmental impacts}

Higher pasture production with the best utilisation possible across scenarios resulted in greater animal production and farm gross margin in years with favourable weather. Far $m$ environmental efficiency (GHG emission and nitrate leaching per unit of animal products) was also improved as weather conditions became more favourable (Table 2). However, variation amplitudes of these farm indicators in response to weather fluctuations were not linearly correlated (Fig. 2). Compared with an average year (Base), weatherinduced inter-annual variation in pasture production ranged from $72 \%$ (Bottom) to $119 \%$ (Top). This modelled variation range is very similar to those observed in Southland (73-121\% in Mona Bush (Smith 2012); 74-128\% in Winton (Radcliffe 1974)). With the management adaptations applied, the variation in pasture production led to a variation range of $85-112 \%$ in animal dry matter consumption, a variation range of $80-117 \%$ in animal production, and a variation range of $7-125 \%$ in farm gross margin.

In the Bottom scenario, management adaptation through increased utilisation of farm-grown and imported supplemental feed offset some of the negative effects of lower pasture production. Thus, the reduction in animal production relative to the Base scenario was smaller than the corresponding reduction in pasture production. However, additional expenditure from imported feed and less income from animal products and contract grazing contributed to a much larger reduction in farm gross margin, as compared with that of pasture production reduction. In a wet year (Top), increased animal feed intake was smaller than increased pasture production due to the relative lack in flexibility around stocking policies. Animal production and pasture herbage production had similar increases under the current assumptions, but the increase of farm gross margin was greater than that of animal production due to a greater margin from surplus hay production, and less cost in bought-in feed.

Nitrate leaching losses and GHG emissions increased with pasture and animal production induced by favourable weather conditions, but their increases were smaller than that of animal production, thus emissions per unit of animal product (i.e., emission intensity) decreased, leading to a higher environmental efficiency under favourable weather conditions (Fig. 2b).

Our results showed that farm economic and environmental efficiencies are both high under favourable weather conditions. This analysis considered only simple on-farm management adaptations in response to unpredictable weather variations; distinct combinations of forage crop production and use of supplemental feed, and contract livestock grazing were amongst these strategies. To a lesser extent, liveweight (LW) gains and the possibility of selling lambs, hoggets and finishing heifers and steers at better prices were also integrated as strategies, particularly to cope with pasture growth above the Base level. Seasonal variation in feed and stock prices was modelled, but not the inter-annual variation. The market change across years (e.g., hay prices are often higher and stock prices are often lower in drought years than in good years) alters the profitability of the same farm system design and associated management tactics. Inclusion of this market fluctuation will most likely reduce the farm margin in both drought and good years, and deserves further analysis.

Although previous modelling exercises have suggested a relatively weak association between GHG emissions/ $\mathrm{N}$ leaching intensity and profit from sheep and beef farming (Dynes et al. 2011; Smeaton et al. 2011), the annual pasture production curves in those studies were much narrower in scope than the ones tested in the current exercise.

The farm system modelling exercise (using Farmax and Overseer) was conducted on an annual basis. Although seemingly kept to a minimum by stock and pasture cover policies, the carryover effects across years, e.g., changes in animal health conditions, soil properties and pasture persistence, were not considered. The dramatic decline in farm gross margin under the Bottom weather scenario may suggest that the rigid pasture and animal management strategies aiming at similar pasture cover and animal numbers at the beginning and end of the modelling exercise may not be optimal for the achievement of best financial farm performance. The effects of management strategies at varying pasture covers and animal numbers 
under different weather scenarios warrants further investigation. The carryover effects of a weather event on farm systems in the following years were not explicitly modelled in this exercise. Modelling the cumulative carryover effects over multiple years or on a long-term sequence, as demonstrated by the HerdEcon model (Korte \& Rhodes 1993), is expected to improve the confidence of the modelling results.

Also, a localised pasture production variation is assumed, thus management adaptation may include importing/exporting supplemental feed from/to neighbouring regions and shortening/ extending contract on-farm grazing from neighbouring farms. The weather-induced changes in farm productivity and profitability would be much larger if the weather variation was synchronised in multiple regions, such as the droughts in 1998 and 2008 (Gray et al. 2008; MAF 2008), because the cost of applying these adaptations would be high due to the large changes in animal feed and stock prices as discussed above.

\section{Conclusion}

Large variation in pasture production across years can be buffered through management adaptations, thus the variation in animal production can be smaller than that of pasture production. However, the smaller variation in animal production may lead to an even larger variation in farm profitability and environmental outcomes. Aiming for high animal production under unfavourable weather scenario with high management inputs may result in low farm profitability. Considering the non-proportional changes among variations in pasture production, animal production, profitability and environmental outcomes of animal farming are helpful when selecting farm management strategies to adapt to variable weather conditions. Farm management decision support tools to incorporate the effects of weather variation, especially the follow-on effects of extreme weather events on farm systems and associated tactics, are needed to help farmers and rural professionals in their decision-making.

\section{ACKNOWLEDGEMENTS}

This work was conducted under the Rural Futures Programme, funded by Ministry of Science and Innovation. The authors wish to thank Mark Liefferring and Val Snow for their comments on an early version of the manuscript.

\section{REFERENCES}

Beef and Lamb New Zealand 2010. Beef and Lamb

New Zealand Economic Service Survey. Accessed 15/05/2012. http://www.beeflambnz.com.
Burton, R.; Peoples, S. 2008. Learning from past adaptations to extreme climatic events: A case study of drought. Part C: Main report. AgResearch Report for MAF Policy - Climate Change. 79pp.

Dynes, R.A.; Smeaton, D.C.; Rhodes, A.P.; Fraser, T.J.; Brown, M.A. 2011. Modelling farm management scenarios that illustrate opportunities farmers have to reduce greenhouse gas emissions while maintaining profitability. Proceedings of the New Zealand Society of Animal Production 71:149-178.

Gray, D. I.; Kemp, P. D.; Kenyon, P. R.; Morris, S. T.; Brookes, I. M.; Matthew, C.; Osborne, M. A. 2008. Strategies used to manage climatic risk: lessons from farmers with expertise in dryland farming. Proceedings of the New Zealand Grassland Association 70: 59-68.

Environment Southland 2012. The Topoclimate Project Information Sheets. Accessed: 15 May 2012 http:// www.es.govt.nz/environment/land.

Keating, B.A.; Carberry, P.S.; Hammer, G.L.; Probert, M.E.; Robertson, M.J.; Holzworth, D.; Huth, N.I.; Hargreaves, J.N.G.; Meinke, H.; Hochman, Z.; McLean, G.; Verburg, K.; Snow, V.; Dimes, J.P.; Silburn, M.; Wang, E.; Brown, S.; Bristow, K.L.; Asseng, S.; Chapman, S.; McCown, R.L.; Freebairn, D.M.; Smith C.J. 2003. An overview of APSIM, a model designed for farming systems simulation. European Journal of Agronomy 18: 267-288.

Korte, C.J.; Rhodes A.P. 1993. Economics of droughttolerant pastures for cattle finishing on Hawke's Bay and Wairarapa hill country farms. Proceedings of the New Zealand Grassland Association 55: 45-49.

Li, F.Y.; Snow, V.O.; Holzworth, D.R. 2011. Modelling the seasonal and geographical pattern of pasture production in New Zealand. New Zealand Journal of Agricultural Research 54: 331-352.

MAF 2008. Meeting the challenges. Key points for getting through droughts. Accessed 15 August 2012 http://maxa.maf.govt.nz/mafnet/rural-nz/emergencymanagement/droughts/ challenges

MAF 2010. Pastoral monitoring 2010. Southland/South Otago hill country sheep and beef. Accessed: 15 May 2012 http://www.maf.govt.nz/news-resources/ publications

Manhire, J. 2010. New Zealand pastoral production. Sheep and beef profiles draft report. The AgriBusiness Group. Prepared for Rural Futures, March 2010.

Radcliffe, J.E. 1974. Seasonal distribution of pasture production in New Zealand II. Southland Plains. New Zealand Journal of Experimental Agriculture 2: 341348.

Smit, B.; McNabb, D.; Smithers, J. 1996. Agricultural adaptation to climatic variation. Climatic Change 33: 7-29. 
Smith, L.C. 2012. Long term pasture growth patterns for Southland New Zealand: 1978 to 2012. Proceedings of the New Zealand Grasslands Association 74: 147-152.

Smeaton, D.C.; Cox, T.; Kerr, S.; Dynes, R. 2011. Relationships between farm productivity, profitability, N leaching and GHG emissions: a modelling approach. Proceedings of the New Zealand Grassland Association 73: 57-61.

Tait, A.; Henderson R.; Turner, R.; Zheng, X.G. 2006 Thin plate smoothing spline interpolation of daily rainfall for New Zealand using a climatological rainfall surface. International Journal of Climatology 26: 2097-2115.

Vibart, R.E.; Vogeler, I.; Devantier, B.; Dynes, R.; Rhodes, T.; Allan, W. 2011. Impact of carbon farming on performance, environmental, and profitability aspects of sheep and beef farming systems in Southland. In: Adding to the knowledge base for the nutrient manager. Eds. Currie, L.D.; Christensen, C.L. Occasional Report No. 24. Fertilizer and Lime Research Centre, Massey University, New Zealand. pp12. http://flrc.massey.ac.nz/ publications.html
Wedderburn, M.; Kingi, T.T.; Mackay, A.D.; Brown, M.; Montes De Oca, O.; Maani, K.; Burton, R.; Campbell, H.; Peoples, S.; Manhire, J.; Dynes, R.; Kaye-Blake, B. 2011. A framework for exploring rural futures through collective learning, Proceedings of the New Zealand Grassland Association 73: 69-74.

Wheeler, D.M.; Ledgard, S.F.; de Klein, C.A.M. 2008. Using the OVERSEER nutrient model to estimate onfarm greenhouse gas emissions. Australian Journal of Experimental Agriculture 48: 99-103.

Wilde, R.H. 2003. Manual for National Soils Database. Landcare Research, Palmerston North, 53pp. 
